\title{
Biometric Indicators and Yield of Tomato under Conventional and Unconventional Biostimulators
}

\author{
Cătălina PEREŞ ${ }^{1}$, Ana CAZACU ${ }^{1}$, Iuliana MOTRESCU ${ }^{1}$, Neculai MUNTEANU ${ }^{1}$, Carmen INCULEŢ ${ }^{1}$, Vasile \\ STOLERU ${ }^{1 *}$
}

${ }^{1}$ University of Agricultural Sciences and Veterinary Medicine, 3 M. Sadoveanu St., Iasi, Romania

*corresponding author: vstoleru@uaiasi.ro

BulletinUASVM Horticulture 76(1) / 2019

Print ISSN 1843-5254, Electronic ISSN 1843-5394

DOI:10.15835/buasvmcn-hort: 2018.0038

\begin{abstract}
The research consisted of an experiment applying unconventional stimulators to tomato crop, as a measure against chemical stimulators, known as having negative effects on human health. In our research there have been used four unconventional stimulators (Ecostim, $\mathrm{AuCl}_{4}-50 \mu \mathrm{g}, \mathrm{AuCl}_{4}-30 \mu \mathrm{g}$ and Chitosan) and a conventional stimulator BNOA, all compared with the untreated control.

Application of stimulators in unconventional farming determined lower productions compared to conventional farming, but is an alternative because determined healthy products. In three of the four unconventional variants, the content of macro- and microelements in plants was higher.
\end{abstract}

Keywords: Lycopersicon esculentum, macro- and microelements, production, stimulator

\section{Introduction}

Sustainable farming is an alternative to intensive agriculture, based on efficient methods and means of production (Stoleru et al., 2014). In conventional agriculture, during the green revolution, many stimulating chemicals such as BNOA, SDMA 2.4-D, Tomato-stim, Atonik have been used to stimulate flower setting, but these products have a negative effect on the human health (Watanabe et al., 2015; Munteanu et al., 2010). The notion of organic farming emerged at the beginning of the 20th century, being a very important area for ensuring sustainable development (Stoleru, 2013). From literature, it is well known that tomato pollen at temperatures above $30{ }^{\circ} \mathrm{C}$, does not germinate and drips very quickly without self-fertilization.

BNOA 2-Naphthoxyacetic acid is a growth regulator that prevents fruit from early dropping and promotes proliferation of roots (Apahidean et al., 2012). BNOA is well known tomato stimulator in the conventional system, but with carcinogenic effects.

Chitosan is a polysaccharide made from chitin, resulted from shrimp shells and other crustaceans with sodium hydroxide. Chitosan has a wide range of uses, both in agriculture, medicine, winemaking and in limiting fat absorption. The product is used to treat seeds, but also as a bio-pesticide, helping plants to fight fungal infections (Malerba et al., 2016; Anitha et al., 2014).

Gold tetrachloride is an anorganic compound used as a precursor in the synthesis of gold nanoparticles, which has various applications in different fields ranging from agricultural and food industry to medicine. It has the potential to stimulate the production of various plants (Siddiqi and Husen, 2016).

Ecostim is a glycoside of furostanol and a natural substance belonging to the saponin class. This product has been obtained by alcoholic extraction from tomato seeds, it is a bioactive 


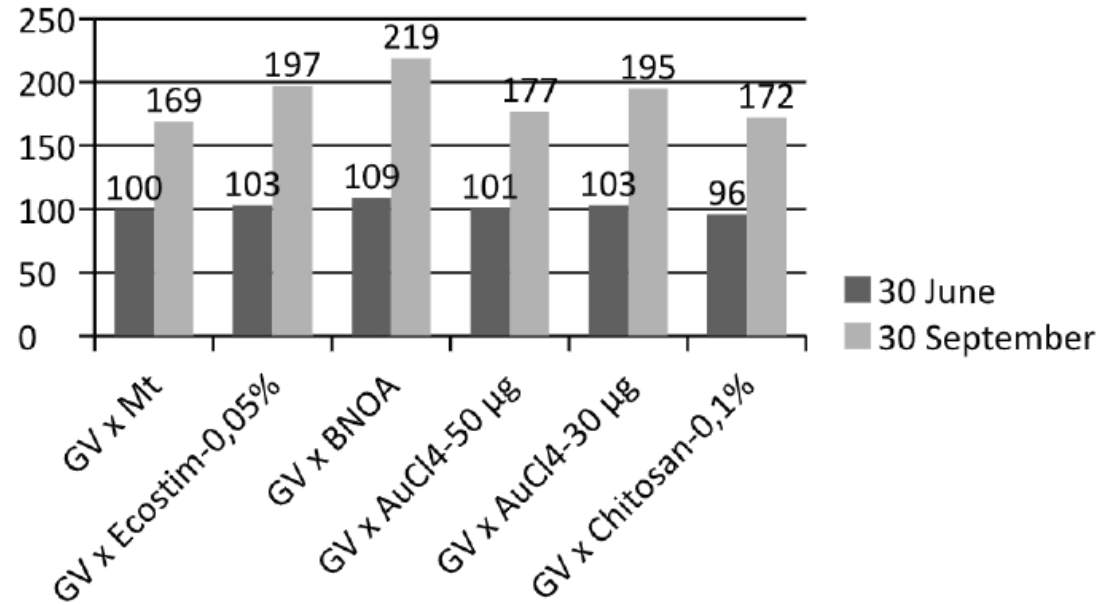

Figure 1. Results of tomato plant height $(\mathrm{cm})$

Table 1. Influence of stimulators on morphological indices of tomato

\begin{tabular}{cccccc}
\hline Treatment & $\begin{array}{c}\text { Inflorescences } \\
\text { per plant }\end{array}$ & $\begin{array}{c}\text { No. of } \\
\text { leaves }\end{array}$ & $\begin{array}{c}\text { No. of flowers } \\
\text { per plant }\end{array}$ & $\begin{array}{c}\text { No. of fruits per Fruit weight } \\
\text { plant }\end{array}$ & $(\mathrm{g})$ \\
\hline Control & 3.02 & 16.06 & 15.7 & 13.5 & 181 \\
\hline Ecostim & 3.24 & 16.72 & 18.1 & 16.9 & 218 \\
\hline BNOA & 4.35 & 18.82 & 29.6 & 27.2 & 207 \\
\hline $\mathrm{AuCl}_{4}-50 \mu \mathrm{g}$ & 3.27 & 17.2 & 18.6 & 16.4 & 190 \\
\hline $\mathrm{AuCl}_{4}-30 \mu \mathrm{g}$ & 3.46 & 16.54 & 20.2 & 18.4 & 201 \\
\hline Chitosan $^{2}$ & 3.20 & 16.48 & 17.7 & 15.4 & 220 \\
\hline
\end{tabular}

substance of plant origin and has antiviral and antifungal properties (Munteanu et al., 2011).

The research aimed to assess the possibilities of using unconventional stimulators for tomato crop, for the preservation of the ecological balance, as compared to chemical stimulation.

\section{Materials and methods}

The research was carried out in a horticultural farm "V. Adamachi "Iasi, with $47^{\circ} 10^{\prime} 37.257^{\prime}$ N $27^{\circ} 30^{\prime} 6.20^{\prime \prime}$ E GPS coordinates using Gravitet F1 tomato. The experiment consisted of 5 treatments: Ecostim-0.05\%, $\quad \mathrm{AuCl}_{4}-50 \mu \mathrm{g}-0.05 \%, \quad \mathrm{AuCl}_{4}-$ $30 \mu \mathrm{g}-0.05 \%$, BNOA-0.1\% and Chitosan-0.1\% compared with the untreated variant, sprayed in water suspension. Each experimental plot comprised 5 plants, in 3 replications, in total 90 harvested tomato, analysed on the $30^{\text {th }}$ of June (803 BBCH) and the $30^{\text {th }}$ of September ( $\left.808 \mathrm{BBCH}\right)$. During the vegetative period determinations were made on the following production indicators: number of flowers and fruits, fruit weight and total yield. Macro- and microelements were analysed by EDXS method.
Statistical analysis was carried out using ANOVA, for degrees of confidence of $95 \%, 99 \%$ and 99.9\%, by SPSS version 20 .

\section{Results and discussions}

Obtaining a sustainable harvest in tomatoes is conditioned by the growth and development of plants. Results on the effect of stimulators on plant growth are presented in Figure 1.

In the first determination ( $30^{\text {th }}$ of June), the average height varied from $96 \mathrm{~cm}$ for Chitosan treatment to $109 \mathrm{~cm}$ for BNOA treatment. In the second determination $\left(30^{\text {th }}\right.$ of September) the height varied between $169 \mathrm{~cm}$ for tomatoes treated with distilled water and $219 \mathrm{~cm}$ for tomatoes treated with BNOA, demonstrating that treatment with conventional bio-stimulators has greatly influenced the plant growth. In the case of gold tetrachloride, the best growth results were achieved by plants treated with $30 \mu \mathrm{g} \mathrm{AuCl}$, the height reaching $195 \mathrm{~cm}$.

All treatments had a positive influence on the vegetative growth of the tomato plants. 
Table 2. Effect of stimulators on tomato yield

\begin{tabular}{ccccc}
\hline Treatment & $\begin{array}{c}\text { Total yield (kg/ } \\
\text { ha) }\end{array}$ & $\begin{array}{c}\text { Relative } \\
\text { production } \%\end{array}$ & $\begin{array}{c}\text { Difference from } \\
\text { control kg/ha }\end{array}$ & $\begin{array}{c}\text { Significance of } \\
\text { difference }\end{array}$ \\
\hline Control & 59,890 & 100 & 0 & ns \\
\hline Ecostim & 90,124 & 150 & 30,234 & $* * *$ \\
\hline BNOA & 138,014 & 230 & 78,124 & $* * *$ \\
\hline AuCl4-50 $\mu \mathrm{g}$ & 76,353 & 127 & 16,463 & $* *$ \\
\hline AuCl4-30 $\mu \mathrm{g}$ & 90,706 & 151 & 30,816 & $* * *$ \\
\hline Chitosan & 83,132 & 139 & 23,242 &
\end{tabular}

ns- not significant; ${ }^{* *}$ - differences distinct positive; ${ }^{* * *}$ - very positive differences

Table 3. Content of macro- and micro-elements in tomato

\begin{tabular}{ccccccc}
\hline \multirow{2}{*}{$\begin{array}{c}\text { Chemical } \\
\text { element } \%\end{array}$} & Control & Ecostim & BNOA & AuCl $_{4}-50 \mu \mathrm{g}$ & AuCl $_{4}-30 \mu \mathrm{g}$ & Chitosan \\
\cline { 2 - 7 } $\mathrm{Ca}$ & 0.4 & 0.3 & 1.8 & 2.0 & 4.8 & 1.8 \\
\hline $\mathrm{Cl}$ & 0.3 & 0.2 & 1.2 & 1.7 & 0.6 & 1.1 \\
\hline $\mathrm{Mg}$ & 0.8 & 0.7 & 0.4 & 0.9 & 1.2 & 0.7 \\
\hline $\mathrm{K}$ & 0.4 & 0.4 & 1.2 & 1.8 & 1.2 & 1.1 \\
\hline $\mathrm{S}$ & 0.1 & 0.1 & 0.1 & 0.2 & 0.3 & 0.2 \\
\hline $\mathrm{Na}$ & 0.0 & 0.0 & 0.0 & 0.2 & 0.1 & 0.0 \\
\hline
\end{tabular}

Following the analysis of tomato plant growth processes, it can be noticed that the height of the plants, the number of leaves and inflorescences are variable, these processes being influenced by the biostimulator used. Among all experimental treatments the most significant increase of tomatoes treated with BNOA can be observed, regarding stem height, number of leaves and inflorescences (Tab. 1).

The number of inflorescences per plant varied according to the treatment, ranging from 3.02 in control to 4.35 in BNOA trated variant. The fruit number varied from 13.5 for control to 27.2 under the same chemical stimulator. Fruit weight ranged from $181 \mathrm{~g}$ in control to $220 \mathrm{~g}$ for Chitosan treatment.

The application of chemical biostimulators revealed the highest yield among all experimental variants with BNOA (138.014 $\left.\mathrm{kg} \mathrm{ha}^{-1}\right)$, while treatment with Ecostim biological stimulator led to a lower yield (90.124 kg ha-1) (Tab. 2).

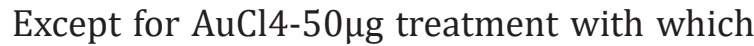
resulted a distinct significant increase of yield for all the other treatments very significant increases of yield were revealed, as compared with control.

Data presented in Table 3 show that macroand micronutrients content in tomato is higher in variants treated with $\mathrm{AuCl}_{4}-50 \mu \mathrm{g}, \mathrm{AuCl}_{4}-30 \mu \mathrm{g}$, Chitosan compared to BNOA. In the variants treated with Ecostim and Control, the mineral content was 2-3 times lower than in the BNOA treated variant.

\section{Conclusion}

Following the analysis of tomato plant growth processes, it can be seen that the height of plants, number of leaves and inflorescences are variable, these characters being influenced by the biostimulator used. From all the analysed variants, a significant increase of stem height, number of leaves and set flowers of tomatoes treated with BNOA can be observed. The other variations in leaf and inflorescences have evolved numerically in parallel with the height.

The results obtained by using Ecostim as nonconventional bio-stimulators increased yield with approximately $50 \%$ than control.

\section{References}

1. Anitha A, Sowmya S, Sudheesh Kumar PT, Deepthi S, Chennazhi KP, Ehrlich H, Tsurkan M, Jayakumar R (2014). Chitin and chitosan in selected biomedical applications. Progress in Polymer Science, 39:1644-1667. 
2. Apahidean A, Maniuţiu D, Apahidean M, Sima R (2012). Cultura legumelor, Editura Risoprint, Cluj-Napoca, chapter 8.

3. Malerba M, Cerana R (2016). Chitosan effects on plant systems. International Journal of Molecular Science, 2016 17, 996:1-15.

4. Munteanu N, Bireescu L, Bulgariu D, Hura C, Stoian L, Stoleru V (2010). Monografia producţiei legumicole ecologice din Nord - Estul României: posibilități și riscuri. Editura "Ion Ionescu de la Brad", Iaşi, chapter 2.

5. Munteanu N, Stoian L, Stoleru V, Bohateret V, Fălticeanu M (2008) - Ghid de bune practici - Modele de conversie la producția legumicolă ecologică, Editura „Ion Ionescu de la Brad", Iași.

6. Muntenu N, Stoleru V, Bireescu L, Bulgariu D, Călin M, Hura C (2011). Flux tehnologic optimizat în legumicultura ecologică pentru siguranța alimentară și sustenabilitate, Editura „Ion Ionescu de la Brad”, Iaşi.

7. Siddiqi KS, Husen A (2016). Engineered Gold Nanoparticles and Plant Adaptation Potential. Nanoscale Research Letters, 11:400. http://doi.org/10.1186/s11671-0161607-2

8. Stoleru V, Munteanu N, Sellitto VM (2014). New Approach of Organic Vegetable Systems, Editura Aracne, Italia.

9. Stoleru V (2013). Managementul sistemelor legumicole ecologice, Editura „Ion Ionescu de la Brad”, Iaşi, chapter 5.

10. Watanabe M, Ohta Y, Lincag S, Motoyama N, Kikuchi J (2015). Profiling contents of water- soluble and mineral nutrients to evaluate the effects of pesticides and organic amd chemical fertilizers on tomato fruit quality. Food chemistry, 169:387-395. 